Section Editor

Mitchell S.V. Elkind, MD, MS

Mystery Case:

\title{
Hemiballism in a patient with parietal lobe infarction
}

自

Meng-Chen Wu, MD

Ruoh-Fang Yen, MD

Chin-Hsien Lin, MD, $\mathrm{PhD}$

Ruey-Meei Wu, MD, $\mathrm{PhD}$

Correspondence to

Dr. Lin:

chlin@ntu.edu.tw
Supplemental data at www.neurology.org
A 60-year-old man with a history of atrial fibrillation had an acute onset of ballistic movements of the left limbs with sensory extinction (video on the Neurol$o g y{ }^{\circledR}$ Web site at www.neurology.org). The patient was treated with risperidone and anticoagulant; symptoms subsided 3 days later. Brain MRI showed acute infarction of the right posterior parietal lobe (figure 1) and SPECT revealed hypoperfusion in the right frontoparietal areas (figure 2).

Hemiballism is a rare movement disorder often associated with lesions in the subthalamic nucleus (STN). Lesions outside the STN are rarely reported., ${ }^{1,2}$ A disorganized sensorimotor integration in frontoparietal lobes resulting in decreased excitatory output to STN probably causes this phenomenon.

\section{STUDY FUNDING}

No targeted funding reported.

\section{DISCLOSURE}

The authors report no disclosures relevant to the manuscript. Go to Neurology.org for full disclosures.

\section{REFERENCES}

1. Srivastava T, Singh S, Goyal V, Shukla G, Behari M. Hemichorea-hemiballism associated with frontoparietal bleed. J Neurol 2006;253:653-654.

2. Mizushima N, Park-Matsumoto YC, Amakawa T, Hayashi $\mathrm{H}$. A case of hemichorea-hemiballism associated with parietal lobe infarction. Eur J Neurol 1997;37:65-66.

Figure 1 MRI of the patient's brain

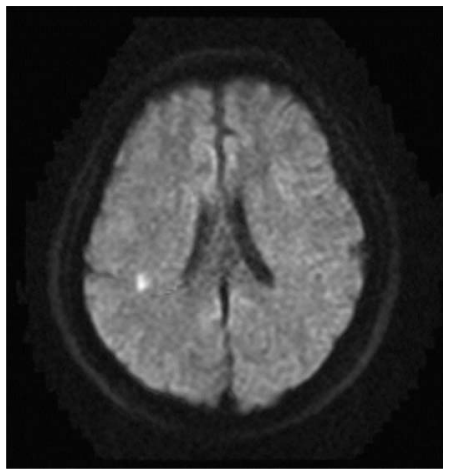

Axial view of diffusion-weighted MRI at frontoparietal level.
MYSTERY CASE RESPONSES The Mystery Case series was initiated by the Neurology ${ }^{\circledR}$ Resident \& Fellow Section to develop the clinical reasoning skills of trainees. Residency programs, medical student preceptors, and individuals were invited to use this Mystery Case as an education tool. Responses were solicited through a group e-mail sent to the American Academy of Neurology Consortium of Neurology Residents and Fellows and through social media. All the answers that we received came from individual residents rather than groups and they were all well-reasoned and thoughtful. Most respondents (over 90\%) correctly identified the involuntary, large-amplitude, flinging movements of the left side limbs as hemiballismus and considered an ischemic stroke as the most likely mechanism; $30 \%$ of respondents considered lesion sites other than the STN, including basal ganglia and cortex.

The teaching point of this Mystery Case is that while most injuries causing hemiballismus occur within the subcortical nuclei (classically the STN), there are reported cases of damage to cortical structures causing hemiballismus. In addition, lesions of the STN usually produce a more severe movement disorder than lesions of other structures. ${ }^{1}$

Dragos A. Nita, MD, PhD

The Hospital for Sick Children, University of Toronto, Toronto, Canada.

\section{REFERENCE}

1. Postum RB, Lang AE. Hemiballism: revisiting a classic disorder. Lancet Neurol 2003;2:661-668.

\section{Figure 2 SPECT images of the patient's brain}
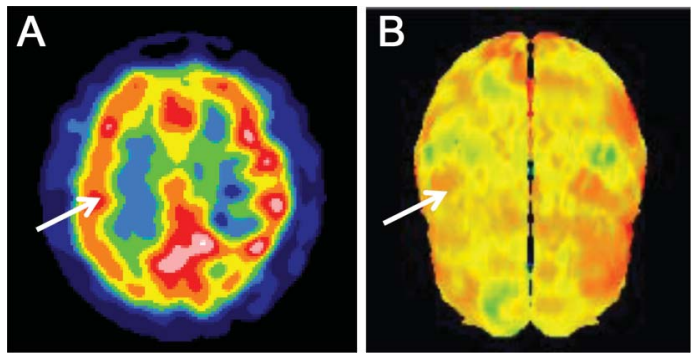

(A) Axial view of SPECT at frontoparietal level. (B) 3D cortical perfusion SPECT image at the same level. The arrows indicate hypoperfusion of right frontoparietal regions.

From the Departments of Neurology (M.-C.W., C.-H.L., R.-M.W.) and Nuclear Medicine (R.-F.Y.), National Taiwan University Hospital, Taipei. 


\section{Neurology}

\section{Mystery Case: Hemiballism in a patient with parietal lobe infarction Meng-Chen $\mathrm{Wu}$, Ruoh-Fang Yen, Chin-Hsien Lin, et al. Neurology 2013;80;e22 \\ DOI 10.1212/WNL.0b013e31827deb11}

This information is current as of January 14, 2013

\begin{tabular}{|c|c|}
\hline $\begin{array}{l}\text { Updated Information \& } \\
\text { Services }\end{array}$ & $\begin{array}{l}\text { including high resolution figures, can be found at: } \\
\text { http://n.neurology.org/content/80/3/e22.full }\end{array}$ \\
\hline Supplementary Material & $\begin{array}{l}\text { Supplementary material can be found at: } \\
\mathrm{http} / / / \text { n.neurology.org/content/suppl/2013/01/12/80.3.e22.DC1 }\end{array}$ \\
\hline References & $\begin{array}{l}\text { This article cites } 3 \text { articles, } 0 \text { of which you can access for free at: } \\
\text { http://n.neurology.org/content/80/3/e22.full\#ref-list-1 }\end{array}$ \\
\hline Subspecialty Collections & $\begin{array}{l}\text { This article, along with others on similar topics, appears in the } \\
\text { following collection(s): } \\
\text { All Movement Disorders } \\
\text { http://n.neurology.org/cgi/collection/all_movement_disorders } \\
\text { Chorea } \\
\text { http://n.neurology.org/cgi/collection/chorea } \\
\text { Embolism } \\
\text { http://n.neurology.org/cgi/collection/embolism } \\
\text { MRI } \\
\text { http://n.neurology.org/cgi/collection/mri } \\
\text { SPECT } \\
\text { http://n.neurology.org/cgi/collection/spect }\end{array}$ \\
\hline Permissions \& Licensing & $\begin{array}{l}\text { Information about reproducing this article in parts (figures,tables) or in } \\
\text { its entirety can be found online at: } \\
\text { http://www.neurology.org/about/about_the_journal\#permissions }\end{array}$ \\
\hline Reprints & $\begin{array}{l}\text { Information about ordering reprints can be found online: } \\
\text { http://n.neurology.org/subscribers/advertise }\end{array}$ \\
\hline
\end{tabular}

Neurology $®$ is the official journal of the American Academy of Neurology. Published continuously since 1951, it is now a weekly with 48 issues per year. Copyright @ 2013 American Academy of Neurology. All rights reserved. Print ISSN: 0028-3878. Online ISSN: 1526-632X.

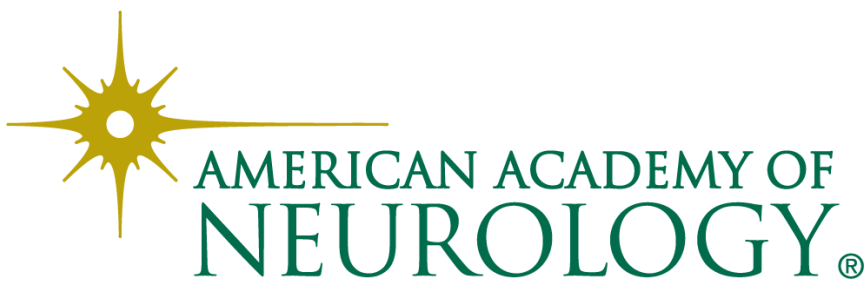

